\title{
IDENTIFIKASI SENYAWA DAN AKTIVITAS ANTIMALARIA IN VIVO EKSTRAK ETIL ASETAT TANAMAN ANTING-ANTING (Acalypha indica L.)
}

\author{
Elok Kamilah Hayati, Akyunul Jannah, Rachmawati Ningsih \\ Jurusan Kimia UIN Maulana Malik Ibrahim Malang \\ Jl. Gajayana No. 50 Malang \\ email: eloksunardji@yahoo.com
}

\begin{abstract}
ABSTRAK
Telah dilakukan penelitian identifikasi ekstrak etil asetat dari tanama Anting-anting (Acalypha indica Linn.) sebagai senyawa antimalaria dan aktivitasnya secara in vivo pada sel parasit malaria $P$. berghei.

Penelitian ini meliputi ekstraksi tanaman anting-anting menggunakan metode ekstraksi maserasi selama 24 jam dengan variasi pelarut yaitu etil asetat, diklorometana, dan petroleum eter. Pengadukkan dibantu dengan shaker selama 3 jam. Ekstrak pekat diuji fitokimia didukung Kromatografi Lapis Tipis, Ekstrak pekat etil asetat dilakukan uji antimalaria in vivo terhadap hewan uji terhadap sel parasit $P$. berghei. Data derajat parasitemia mencit dianalisis menggunakan program SPSS dengan Uji OneWay ANOVA dan dilanjutkan dengan Uji Tukey.

Hasil penelitian menunjukkan adanya senyawa aktif tanin, alkaloid dan steroid pada ekstrak etil asetat.Uji aktivitas antimalaria secara in vivo pada hewan coba didapatkan hasil penghambatan ekstrak etilasetat terhadap pertumbuhan Plasmodium berghei pada dosis $0,01 \mathrm{mg} / \mathrm{g}$ bb sebesar $87,19 \%$; pada dosis $0,1 \mathrm{mg} / \mathrm{g}$ bb sebesar $84,9 \%$ dan pada dosis $1 \mathrm{mg} / \mathrm{g}$ bb sebesar $90,74 \%$.
\end{abstract}

Kata kunci: Anting-anting (Acalypha indica L.), antimalaria in vivo, Plasmodium berghei

\section{COMPOUNDS IDENTIFICATION AND IN VIVO ANTIMALARIAL ACTIVITY OF ETHYL ACETATE EXTRACT FROM ANTING-ANTING PLANT (Acalypha indica L.)}

\begin{abstract}
Research of compound identification of ethyl acetate extract from anting-anting plant (Acalypha indica Linn.) and in vivo antimalarial activity test in cell of the malaria parasite $P$. berghei

The research consist of extraction of Anting-anting plant was done with extraction maseration method until 24 hours and shakered until 3 hours. Variation of solvents are ethyl acetate, dichloromethane and petroleum ether. Concentrated extract was in vivo antimalarial tested to animal model. Data of mice parasitemia degree was analyzed using SPSS program with OneWay ANOVA Test dan continued with Tukey Test.

The phytochemical compounds in each solvent extract are tannin, alkaloid and steroid in ethyl acetate extract. The value of parasite inhibition is $87,19 \%$ for dose 0.01 $\mathrm{mg} / \mathrm{g} \mathrm{wb} ; 84.9 \%$ for dose $0.1 \mathrm{mg} / \mathrm{g} \mathrm{wb} ; 90.74 \%$ for dose $1 \mathrm{mg} / \mathrm{g} \mathrm{wb}$.
\end{abstract}

Keywords: Anting-anting (Acalypha indica Linn.), in vivo antimalarial, Plasmodium berghei 


\section{PENDAHULUAN}

Di Indonesia penyakit malaria termasuk masalah kesehatan masyarakat yang cukup serius di tangani oleh pemerintah, karena angka kematian yang cukup tinggi terutama di Indonesia bagian timur yang menjadi daerah endemik penyakit malaria ini (Antara News, 2007). Malaria adalah salah satu penyakit menular yang tersebar ke seluruh dunia, sekitar 350-500 juta orang terinfeksi penyakit ini dan lebih dari 1 persen kematian setiap tahun. Malaria disebabkan oleh parasit protozoa. Plasmodium (salah satu Apicomplexa) dan penularan vektor untuk parasit malaria manusia adalah nyamuk Anopheles (Ito et al., 2002), spesies malaria yang paling berbahaya adalah $P$. falciparum.

Malaria merupakan penyebab utama kematian manusia di negara berkembang dan beriklim tropis. Pertumbuhan penduduk yang cepat, migrasi, sanitasi yang buruk, serta daerah yang terlalu padat, membantu memudahkan penyebaran penyakit tersebut. Penyakit ini menjadi ancaman yang serius mengingat akhir-akhir ini banyak dilaporkan resistensi terhadap $P$. falciparum dari hampir semua obat antimalaria yang tersedia secara komersial seperti klorokuin dan kuinin. Di Papua tiga jenis obat penyakit malaria, yaitu cloroquin, piremetamin dan sulvadoxin, saat ini sudah tidak mampu lagi mengobati (resisten) untuk mengobati pasien malaria.

Dengan mempertimbangkan sejauh ini belum ditemukannya obat malaria yang efektif, usaha penemuan obat antimalaria baru menjadi salah satu prioritas utama terutama yang berasal dari alam sebagai salah satu usaha eksplorasi terhadap kekayaan alam yang di miliki oleh Indonesia.

Tumbuhan obat di Indonesia cukup melimpah, tetapi pemanfaatannya hanya sebatas penggunaan secara tradisional, hanya sebagian kecil saja, sekitar 7.000 spesies dari 30.000 spesies yang telah dilakukan penelitian secara ilmiah. Masih banyak spesies yang belum dikenal manfaat, kandungan kimia dan bioaktivitasnya.

Selama ini obat bahan alam yang sering digunakan untuk proses pengobatan penyakit ini adalah getah dari batang pohon cinchona, yang lebih dikenal dengan nama kina, yang sebenarnya beracun dan menekan pertumbuhan protozoa dalam jaringan darah. Oleh karena itu perlu mencari sumber tanaman lain yang selama ini telah dipercaya oleh masyarakat untuk menyembuhkan penyakit malaria, yang berpeluang mempunyai sifat toksik untuk dapat dikembangkan menjadi senyawa antimalaria.

Senyawa artemisinin pada tanaman Artemisia annua, Artemisia cina dan Artemisia vulgaris bersifat aktif sebagai antimalaria dengan tingkat kematian plasmodium $85,77 \%$ pada konsentrasi zat uji $100 \mu \mathrm{g} / \mathrm{mL}$, senyawa artemisisn merupakan senyawa siskuterpen yang relatif bersifat non-polar (Aryanti dkk., 2006). Ekstrak diklorometan dari Oncosiphon piluliferum (Asteraceae) mengandung senyawa sesquiterpen lakton tipe the germacranolide dan eudesmanolide yang bersifat aktif antimalaria $\begin{array}{llll}\left(\mathrm{IC}_{50}\right. & 0.4 & \text { to } & 4.4 \quad \mathrm{~g} / \mathrm{ml})\end{array}$ (Pillay et al.., 2007). Senyawa tinokrisposid, suatu furanoditerpenglikosida dari batang Brotowoli (Tinospora crispa L) dapat menekan perkembangan $P$. berghei dalam darah mencit dan memperpanjang hidup mencit yang terinfeksi. Efek optimal diberikan pada dosis $44 \mathrm{mg} / \mathrm{kg}$ bb (Zambrut dkk., 2011). Sedangkan senyawa flavonoid pada buah Cempedak (Artocarpus champeden Spreng) memiliki aktivitas antimalaria yang poten, melalui hambatan degradasi hemoglobin dan detoksifikasi 
heme serta mekanisme lain yang belum diketahui (Nindatu, 2008).

Anting-anting (Acalypha australis L.), dikenal sebagai jenis gulma, tanaman liar yang sering dijumpai di pinggir jalan, lapangan rumput yang tidak terawat bahkan sebagai pengganggu di lahan pertanian. Keberadaannya yang melimpah dan mudah diperoleh inilah yang memberikan peluang tanaman ini dapat ditingkatkan nilai gunanya. Komponen yang terkandung dalam tanaman ini adalah $\beta$-sitosterol dan daucosterol (Wei-Fang, 1994), saponin, tannin, flavonoid dan minyak atsiri (Anonim, 2009). Tanaman Anting-anting oleh masyarakat digunakan untuk menyembuhkan penyakit enzema, pendaharahan pada rahim, radang kulit (Wei-Fang, 1994), disentri basiler dan disentri amuba, diare, malnutrition, mimisan, muntah darah, berak darah, kencing darah, serta malaria (IPTEKnet, 2005).

Sebagai tanaman yang digunakan untuk mengobati penyakit malaria, penggunaan tanaman anting-anting hanya sebatas pada khasiat turuntemurun. Belum diketahui senyawa aktif yang mempunyai potensi sebagai antimalaria. Oleh karena itu perlu dilakukannya penelitian, guna mengetahui potensi tanaman anting-anting sebagai antimalaria. Kedepan, harapannya dapat ditemukan senyawa sintesis dari hasil penelitian ini. Hasil penelitian sebelumnya menunjukkan, masing-masing ekstrak tanaman anting-anting (Acalypha indica L.) memiliki tingkat toksisitas terhadap larva udang Artemia salina Leach, ditunjukkan dengan nilai $\mathrm{LC}_{50}<1000$ ppm. Adapun nilai $\mathrm{LC}_{50}$ untuk ekstrak etil asetat, diklorometan dan petroleum eter berturut-turut adalah 21,006 ppm , $17,6495 \quad \mathrm{ppm}, \quad 11,8547 \quad \mathrm{ppm})$ (Sriwahyuni, 2010)

Penelitian ini bertujuan untuk mengetahui jenis kandungan golongan senyawa yang terdapat dalam ekstrak etil asetat tanaman anting-anting (Acalypha indica L.) dari uji fitokimia dan KLT (Kromatografi Lapis Tipis) serta aktivitas ekstrak terhadap sel parasit malaria $P$. berghei secara in vivo.

\section{METODE PENELITIAN}

Penelitian pada tahun pertama, tahap awal tanaman Anting-anting dibersihkan lalu dipisahkan batang dan daun kemudian dikeringkan dan diblender, kemudian dilakukan ekstraksi secara betingkat dengan pelarut petrolium eter, diklorometan, dan etil asetat dengan tujuan mendapatkan senyawa aktif berdasarkan kepolarannya. Ekstrak kering petroleum eter, diklorometan, dan etil asetat yang diperoleh kemudian ditentukan rendemen, dilakukan uji penapisan fitokimia, KLT, serta uji aktivitas antimalaria ekstrak etil asetat secara in vivo terhadap sel parasit malaria P. berghei.

\section{Persiapan Sampel}

Sebayak $5 \mathrm{~kg}$ tanaman Anting-anting (Acalypha indicaL.) diperoleh dari daerah Dinoyo Malang. Tanaman Anting-anting dibersihkan lalu dipisahkan batang dan daun kemudian dikeringkan. Setelah kering, bagian batang dan daun dihaluskan secara terpisah dengan blender, sehingga diperoleh sampel berupa serbuk batang dan daun Anting-anting.

\section{Ekstraksi Senyawa Aktif}

Masing-masing 50 gram serbuk batang dan daun tanaman Anting-anting dimaserasi dengan pelarut petroleum eter selama satu kali 24 jam pada suhu kamar, selanjutnya disaring. Ampas yang tersisa dimaserasi kembali sampai senyawa yang ada tertarik semua (larutan berwarna bening). Ektrak cair yang diperoleh pelarutnya diuapkan dengan rotavapor 
sehingga diperoleh ekstrak petroleum eter.

Ampas hasil maserasi petroleum eter dikeringkan dan dianginkan, lalu dimaserasi lagi dengan menggunakan pelarut diklorometan (pelarut semi polar). Maserasi dilakukan selama satu kali 24 jam pada suhu kamar, selanjutnya disaring, sampai senyawa yang ada tertarik semua (larutan berwarna bening). Ektrak cair yang diperoleh pelarutnya diuapkan dengan rotavapor sehingga diperoleh ekstrak diklorometan,

Proses ekstraksi terakhir yaitu menggunakan pelarut etil asetat (pelarut polar). Ampas hasil maserasi diklorometan dikeringkan dan dianginkan, lalu dimaserasi lagi dengan menggunakan pelarut etil asetat. Maserasi juga dilakukan selama satu kali 24 jam pada suhu kamar, selanjutnya disaring, sampai senyawa yang ada tertarik semua (larutan berwarna bening). Ekstrak cair yang diperoleh pelarutnya diuapkan dengan rotavapor sehingga diperoleh ekstrak etilasetat. Ekstrak etil asetat dihitung rendemennya dan dilakukan analisis lanjutan.

\section{Pemeriksaan Kandungan Senyawa Metabolit Sekunder}

Pemeriksaan kandungan senyawa metabolit sekunder secara kualitatif pada ekstrak etil asetat tanaman Anting-anting dilakukan dengan metode fitokimia terhadap senyawa flavonoid, tanin, terpenoid, alkaloid dan saponin, serta metode kromatografi lapis tipis (KLT).

\section{Aktivitas Antimalaria secara In vivo (Mencit Terinfeksi Plasmodium brghei)}

Uji aktivitas fraksi etil asetat dilakukan dengan berbagai variasi dosis. Pada uji ini mencit positif terinfeksi parasit malaria P. falciparum dikelompokkan menjadi 6 kelompok perlakuan, masing-masing kelompok terdiri dari 5 mencit. Dosis yang digunakan adalah 0,$01 ; 0,1$; dan 1 dan $\mathrm{mg} / \mathrm{g}$ bb tikus. Pada uji variasi dosis juga digunakan kelompok kontrol negatif (CMC 1\%), sedang kontrol positif adalah artemisin dosis $0,04 \mathrm{mg} / \mathrm{g}$. Tingkat parasitemia awal dihitung dengan mengambil darah dari ekor untuk dibuat preparat apus seperti pada pemberian dosis tunggal. Selanjutnya setelah pemberian ekstrak, darah diambil setiap hari selama 7 hari berturut-turut untuk dibuat preparat apus dan dihitung tingkat parasitemianya. Data yang diperoleh dianalisis menggunakan Probit Analysis Method untuk menemukan $\mathrm{IC}_{50}$ dengan selang kepercayaan $95 \%$.

\section{Analisis Data}

Data yang diperoleh dibuat dalam bentuk tabel dan grafik, kemudian dideskripsikan hasilnya. Sedangkan untuk mengetahui tingkat mortalitas larva udang Artemia salina Leach dilakukan uji $\mathrm{LC}_{50}$ dengan analisis probit menggunakan program SPSS 16.00 dengan Uji One Way ANOVA yang dilanjutkan dengan Uji Tukey. Nilai efektif dosis $50 \% \quad\left(\mathrm{ED}_{50}\right)$ dihitung berdasarkan analisis probit $\%$ penghambatan pertumbuhan parasit selama 7 hari.

\section{HASIL DAN PEMBAHASAN}

\section{Preparasi Sampel}

Pengeringan

tanaman

Anting-anting dimaksudkan untuk mengurangi kadar air, menghentikan reaksi enzimatis, dan mencegah tumbuhnya jamur sehingga dapat disimpan lebih lama (pengawetan), tidak mudah rusak sehingga komposisi kimianya tidak mengalami perubahan. Sampel yang telah kering berwarna hijau kecoklatan ini dihaluskan menggunakan blender sehingga diperoleh serbuk sampel yang berwarna hijau kecoklatan. 
Pembuatan serbuk dapat mempermudah proses ekstraksi. Semakin kecil bentuknya semakin besar luas permukaannya maka interaksi zat cairan ekstraksi akan semakin besar, sehingga proses ekstraksi akan semakin efektif. Serbuk dengan penghalusan yang tinggi kemungkinan sel-sel yang rusak juga semakin besar, sehingga memudahkan pengambilan bahan kandungan langsung oleh bahan pelarut (Octavia, 2009).

\section{Ekstraksi Senyawa aktif}

Serbuk sampel ditimbang sebanyak $30 \mathrm{~g}$ dengan 2 kali ulangan, kemudian diekstraksi dengan variasi pelarut berdasarkan kepolarannya agar senyawa yang terkandung dalam tanaman ini dapat terekstrak ke dalam pelarut berdasarkan tingkat kepolarannya tersebut. Ektsraksi yang digunakan yaitu dengan ekstraksi maserasi karena pengerjaannya cukup sederhana. Pada prinsipnya metode maserasi adalah terdapat waktu kontak yang cukup antara pelarut dengan bahan yang diekstrak. Hasil maserasi maksimal biasanya dilakukan dengan maserasi menggunakan sederetan pelarut secara berganti-ganti atau metode Charauxs- Paris yaitu metode ekstraksi dengan menggunakan pelarut yang berbeda kepolaran, dimana ekstrak pekat pelarut polar diekstraksi kembali dengan pelarut semipolar dan pelarut non polar (Kusnaeni, 2008).

Maserasi dilakukan dengan cara merendam serbuk sampel selama 24 jam ke dalam pelarutnya. Proses pengadukannya dibantu dengan shaker selama 3 jam dengan kecepatan 120 rpm untuk mempercepat proses ekstraksinya karena kecepatan pengadukannya dapat dilakukan secara konstan. Pelarut akan menembus dinding sel dan masuk ke dalam rongga sel yang mengandung senyawa aktif. Senyawa aktif akan larut karena adanya perbedaan konsentrasi antara larutan senyawa aktif di dalam dan di luar sel, maka cairan hipertonis akan masuk ke cairan yang hipotonis sehingga terjadi keseimbangan. Pengadukan diperlukan untuk meratakan konsentrasi larutan di luar serbuk sampel sehingga tetap terjaga adanya derajat perbedaan konsentrasi yang sekecil-kecilnya antara larutan di dalam dan di luar sel (Baraja, 2008).

Filtrat hasil dari maserasi masingmasing pelarut yang telah diperoleh diuapkan pelarutnya dengan rotary evaporator vaccum untuk mendapatkan ekstrak pekat seperti yang tersaji pada Tabel 1.

\section{Uji Fitokimia dengan Reagen}

Uji fitokimia dilakukan untuk mengetahui kandungan senyawa ekstrak etil asetat pada tanaman Anting-anting. Pengujian dilakukan dengan mengambil sedikit sampel ekstrak etil asetat. Uji fitokimia dilakukan terhadap golongan senyawa flavonoid, tanin, alkaloid, triterpenoid, steroid dan saponin.

Tabel 1. Hasil maserasi serbuk tanaman Anting-anting(Acalypha indica L.)

\begin{tabular}{|l|l|l|l|}
\hline Pelarut & Perubahan warna filtrat & $\begin{array}{l}\text { Warna } \\
\text { ekstrak } \\
\text { pekat }\end{array}$ & $\begin{array}{l}\text { Berat ekstrak } \\
\text { pekat (g) }\end{array}$ \\
\hline Etil asetat & Hijau tua pekat menjadi hijau pucat & hijau tua & 4,47 \\
\hline Diklorometana & $\begin{array}{l}\text { Hijau kecoklatan pekat menjadi } \\
\text { hijau kecoklatan pucat }\end{array}$ & $\begin{array}{l}\text { hijau tua } \\
\text { kecoklatan }\end{array}$ & 4,00 \\
\hline Petroleum eter & kuning pekat menjadi kuning pucat & $\begin{array}{l}\text { kuning } \\
\text { kehijauan }\end{array}$ & 1,90 \\
\hline
\end{tabular}


Tabel 2.Uji fitokimia ekstrak etil asetat (Acalypha indica L.)

\begin{tabular}{|c|c|}
\hline $\begin{array}{c}\text { Golongan } \\
\text { senyawa }\end{array}$ & Ekstrak etil asetat \\
\hline Flavonoid & - \\
\hline Tanin & + \\
\hline Alkaloid & + \\
\hline Triterpenoid & - \\
\hline Steroid & ++ \\
\hline Saponin & - \\
\hline
\end{tabular}

Keterangan:

Tanda ++ : terkandung senyawa lebih banyak/warna pekat

Tanda + : terkandung senyawa/warna muda

Tanda - : tidak terkandung senyawa/ tidak terbentuk warna

\section{Uji Fitokimia dengan KLT}

Hasil identifikasi fitokimia dengan reagen yang bersifat positif adalah tanin, alkaloid dan steroid, hal ini menunjukkan dugaan adanya senyawa tersebut dalam ekstrak etil asetat tanaman Anting-anting. Pembuktian kandungan senyawa-senyawa tersebut diperkuat dengan adanya identifikasi menggunakan kromatografi lapis tipis (KLT). Noda yang dihasilkan selanjutnya dideteksi dengan pereaksi sesuai golongan senyawanya, kemudian diamati di bawah lampu UV. Pereaksi ini digunakan untuk menambah kepekaan deteksi dan menghasilkan perubahan warna yang ada kaitannya dengan struktur senyawa yang bersangkutan

\section{Tanin}

Hasil identifikasi menggunakan KLT golongan senyawa tanin pada tanaman anting-anting dengan menggunakan eluen asam asetat glasial:air: $\mathrm{HCl}$ pekat (30:10:3) ditunjukkan pada Gambar 1.

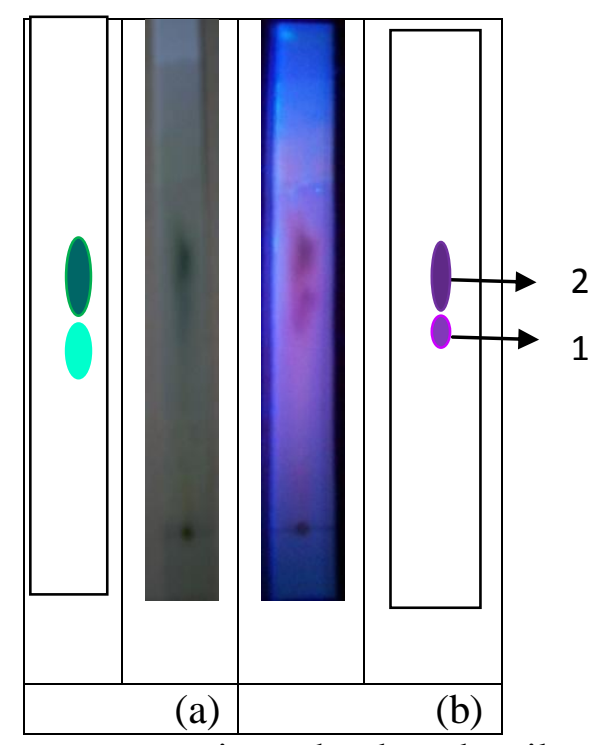

Gambar 1 Hasil KLT senyawa tanin pada ekstrak etil asetat dengan eluen asam asetat glasial: air: $\mathrm{HCl}$ pekat (30:10:3) setelah disemprot $\mathrm{FeCl}_{3}$

Keterangan:

(a) hasil elusi sebelum dideteksi dengan lampu UV

(b) hasil pengamatan dengan lampu UV $366 \mathrm{~nm}$ 
Tabel 3. Hasil KLT senyawa tanin pada ekstrak etil asetat dengan eluen asam asetat glasial: air: $\mathrm{HCl}$ pekat $(30: 10: 3)$

\begin{tabular}{|c|c|c|c|}
\hline No. noda & Rf tiap noda & $\begin{array}{c}\text { Warna noda } \\
\text { tanpa sinar UV }\end{array}$ & $\begin{array}{c}\text { Warna noda dengan } \\
\text { sinar UV }\end{array}$ \\
\hline 1 & 0,4 & Biru muda & Ungu kehitaman \\
\hline 2 & 0,489 & Hijau kebiruan & Ungu \\
\hline
\end{tabular}

Harborne menyatakan bahwa senyawa tanin jika dideteksi di bawah sinar UV pendek menunjukkan warna lembayung, pada penelitian ini noda yang dihasilkan pada eluen butanol:asam asetat:air dan eluen asam asetat glasial, air dan $\mathrm{HCl}$ pekat noda ke 1 menunjukkan warna ungu dan noda ke 2 menunjukkan warna ungu kehitaman, sehingga kedua noda yang dihasilkan pada ekstrak etil asetat diasumsikan mengandung senyawa tanin. Hal ini didukung oleh Hayati (2010) yang menyatakan bahwa noda hasil KLT yang diduga senyawa tanin berwarna ungu kehitaman.

\section{Alkaloid}

Hasil identifikasi menggunakan KLT golongan senyawa alkaloid pada tanaman Anting-anting dengan menggunakan kloroform:methanol $(9,5: 0,5)$ ditunjukkan pada Gambar 2. Penelitian lain tentang senyawa alkaloid menggunakan KLT dengan eluen methanol: kloroform antara lain penelitian Runadi (2007) noda yang dihasilkan berwarna kuning, biru keunguan dan oranye. Minarti (2010) menyatakan bahwa noda berwarna jingga setelah disemprot dengan reagen Dragendorf dan berwarna kuning oranye setelah dideteksi di bawah lampu UV 366 nm (Widodo, 2007). Pada eluen pertama terdapat 4 noda dengan Rf antara $0,56-0,8$. Noda ke 3 menunjukkan warna jingga kehitaman dan pada eluen yang kedua terdapat 5 noda dengan $\mathrm{Rf}$ antara $0,27-0,87$. Noda ke 4 dan 5 menunjukkan warna jingga kecoklatan sehingga diasumsikan pada ekstrak etil asetat terdapat senyawa alkaloid.

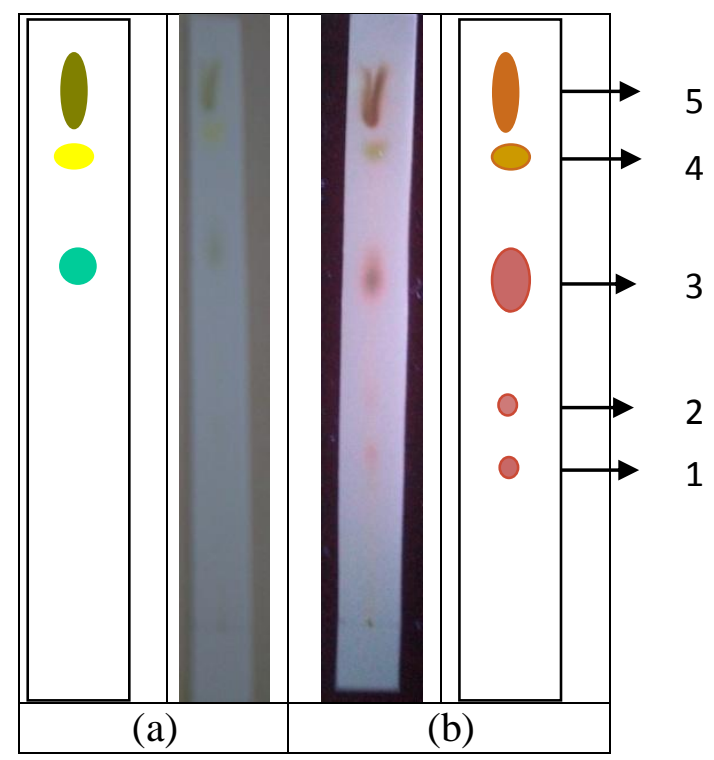

Gambar 2. Hasil KLT senyawa alkaloid pada ekstrak etil asetat dengan eluen kloroform : metanol $(9,5: 0,5)$ setelah disemprot reagen Dragendroft

Keterangan: (a) hasil elusi sebelum dideteksi dengan lampu UV

(b) hasil pengamatan dengan lampu UV $366 \mathrm{~nm}$ 
Tabel 4. Hasil KLT senyawa alkaloid pada ekstrak etil asetat dengan eluen kloroform:metanol $(9,5: 0,5)$

\begin{tabular}{|c|c|c|c|}
\hline No. noda & Rf tiap noda & $\begin{array}{c}\text { Warna noda tanpa } \\
\text { sinar UV }\end{array}$ & $\begin{array}{c}\text { Warna noda dengan sinar } \\
\text { UV }\end{array}$ \\
\hline 1 & 0,27 & Tidak berwarna & Ungu kecoklatan \\
\hline 2 & 0,32 & Tidak berwana & Merahmuda keunguan \\
\hline 3 & 0,58 & Hijau kebiruan & $\begin{array}{c}\text { Ungu kecoklatan tengah } \\
\text { hijau tua }\end{array}$ \\
\hline 4 & 0,78 & Kuning & Jingga kecoklatan \\
\hline 5 & 0,87 & Hijau kecoklatan & Jingga kecoklatan tua \\
\hline
\end{tabular}

\section{Steroid}

Hasil identifikasi menggunakan KLT golongan senyawa steroid pada tanaman anting-anting dengan menggunakan eluen heksana:etil asetat (7:3) ditunjukkan pada Gambar 3. Penelitian sebelumnya (Handayani dkk., 2008) hasil KLT golongan senyawa steroid dengan pereaksi Lieberman-Burchard menunjukkan terbentuknya noda berwarna hijau. Biru ungu sampai coklat setelah dideteksi di bawah lampu UV 366 nm (Syamsudin, 2007). Pada ekstrak etil asetat menunjukkan $\mathrm{Rf}$ antara 0,06-0,82 dengan 9 noda. Noda ke 1, 2 dan 8 menunjukkan warna hijau kebiruan, noda ke 4 menunjukkan warna hijau, noda ke 6 menunjukkan warna ungu yang tengahnya berwarna biru kehijauan, noda ke 9 menunjukkan warna hijau kebiruan muda.

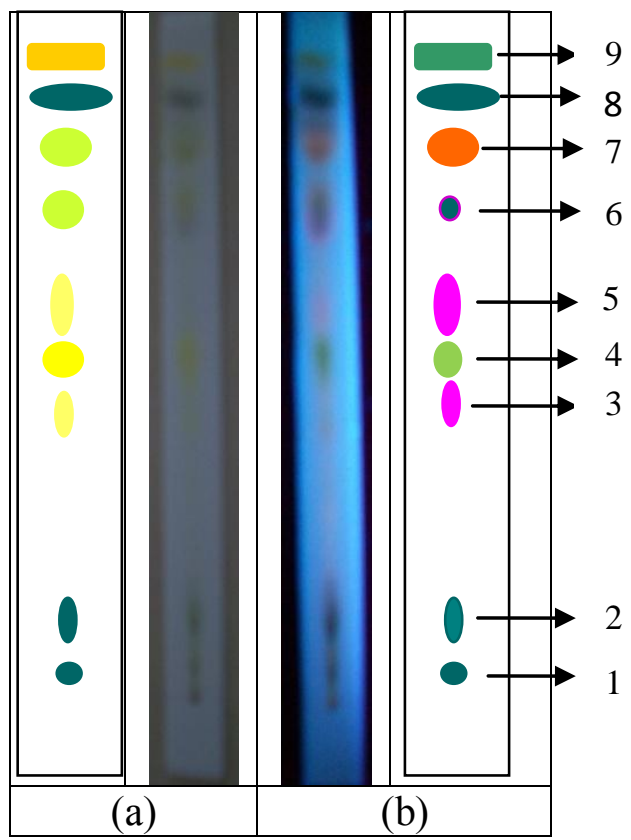

Gambar 3. Hasil KLT senyawa steroid pada ekstrak etil asetat dengan eluen n-heksana: etil asetat (7:3) setelah disemprot reagen Lieberman-Burchard Keterangan: (a) hasil elusi sebelum dideteksi dengan lampu UV

(b) hasil pengamatan dengan lampu UV $366 \mathrm{~nm}$ 
Tabel 5. Hasil KLT senyawa steroid ekstrak etil asetat dengan n-heksana:etil asetat (7:3)

\begin{tabular}{|c|c|c|c|}
\hline No. noda & Rf tiap noda & Warna noda tanpa sinar UV & Warna noda dengan sinar UV \\
\hline 1 & 0,06 & Hijau kebiruan & Hijau kebiruan \\
\hline 2 & 0,11 & Hijau kebiruan & Hijau kebiruan \\
\hline 3 & 0,38 & Kuning & Merah muda \\
\hline 4 & 0,47 & Kuning & Hijau \\
\hline 5 & 0,56 & Kuning & Merah muda \\
\hline 6 & 0,68 & Kuning kehijauan & Ungu tengah biru kehijauan \\
\hline 7 & 0,77 & Kuning kehijauan & Oranye \\
\hline 8 & 0,8 & Hijau kebiruan & Hijau kebiruan \\
\hline 9 & 0,83 & Oranye & Hijau kebiruan muda \\
\hline
\end{tabular}

Uji Aktivitas Antimalaria secara In vivo (MencitTerinfeksi Plasmodium berghei)

Uji aktivitas antimalaria in vivo dilakukan dengan menggunakan metode Fitri L.E modifikasi dari metode Peter. Hewan uji yang digunakan adalah mencit putih jantan galur Balb/C. Terapi dilakukan ketika derajat parasitemia setelah infeksi mencapai $5-15 \%$ yang dihitung sebagai hari ke-0. Terapi dilakukan sekali sehari secara per-oral dengan menggunakan sonde lambung. Terapi diberikan selama 7 hari dengan tujuan diharapkan dalam waktu tujuh hari sudah dapat menghambat pertumbuhan parasit secara efektif.

Ekstrak yang akan diujikan adalah ekstrak etil asetat. Berturut-turut dengan dosis $0,01 \mathrm{mg} / \mathrm{g} \mathrm{bb} ; 0,1 \mathrm{mg} / \mathrm{g}$ bb; dan 1 $\mathrm{mg} / \mathrm{g}$ bb. Pengamatan derajat parasitemia dilakukan pada hari ke-0, hari ke-3, hari ke-5, dan hari ke-7. Hal ini bertujuan untuk mengetahui profil pertumbuhan parasit setelah diberikan pengobatan. Pemeriksaan parasitemia hari ke-0 bertujuan untuk membuktikan semua mencit berada dalam range derajat parasitemia yang sama pada hari akan dilakukan pengobatan (Muti'ah, 2010). Hasil pemeriksaan derajat parasitemia ditunjukkan pada Tabel 6.

Rata-rata derajat parasitemia semua perlakuan pada hari ke-0 adalah sebesar 6-10\%. Perlakuan kelompok kontrol positif menunjukkan derajat parasitemia tertinggi dibandingkan kelompok perlakuan terapi ekstrak etil asetat Anting-anting 1, Anting-anting 2, dan Anting-anting 3 baik pada hari ke-3, hari ke-5, maupun hari ke-7.

Derajat parasitemia diperoleh dari sediaan darah tipis dengan menghitung jumlah sel yang terinfeksi Plasmodium berghei (trofozoid bentuk cincin, trofozoid stadium lanjut, dan atau skizon) dalam 1000 eritrosit (Sardjono dan Fitri, 2007). Eritrosit yang mengandung trofozoit tua dan skizon mempunyai titik-titik kasar yang tampak jelas (titik Maurer) tersebar pada dua pertiga bagian eritrosit. Hasil pengamatan hapusan darah perlakuan kontrol yang diinfeksi Plasmodium berghei tanpa terapi disajikan pada Gambar 6. 
Tabel 6. Rerata derajat parasitemia ekstrak etil asetat Anting-anting

\begin{tabular}{|c|c|c|c|c|}
\hline \multirow{2}{*}{$\begin{array}{c}\text { Kelompok } \\
\text { perlakuan }\end{array}$} & \multicolumn{4}{|c|}{ Rerata derajat parasitemia (\%) } \\
\cline { 2 - 5 } & Hari ke-0 & Hari ke-3 & Hari ke-5 & Hari ke-7 \\
\hline Kontrol positif & 7,00 & 33,53 & 51,37 & 65,90 \\
\hline Anting-anting 1 & 8,30 & 10,03 & 13,77 & 8,43 \\
\hline Anting-anting 2 & 6,67 & 14,40 & 11,97 & 9,93 \\
\hline Anting-anting 3 & 10,07 & 12,30 & 12,63 & 6,10 \\
\hline
\end{tabular}

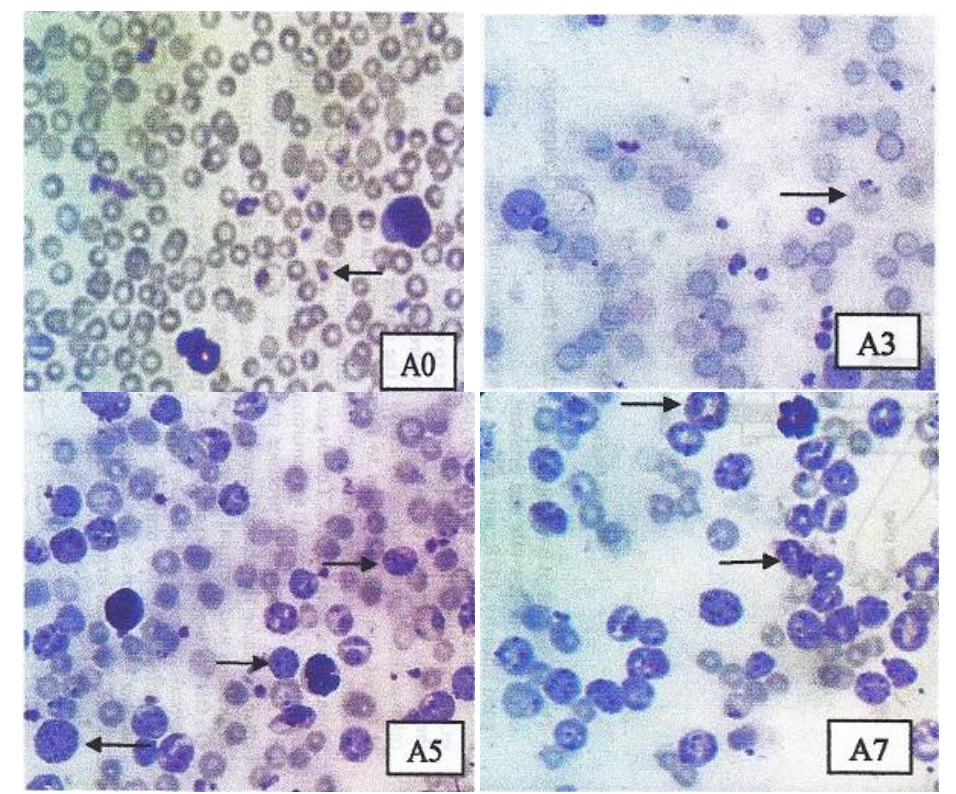

Gambar 6. Gambaran eritrosit terinfeksi kelompok kontrol (+) tanpa terapi pada hari ke-0, hari ke-3, hari ke-5, dan hari ke-7.

Gambar 6 di atas terlihat jumlah eritrosit yang terinfeksi Plasmodium berghei semakin meningkat seiring dengan bertambahnya hari perlakuan. Rata-rata derajat parasitemia pada hari ke-0 (A0) adalah sebesar $7 \%$. Eritrosit terinfeksi (trofozoid bentuk cincin) ditunjukkan oleh tanda panah. Rata-rata derajat parasitemia hari ke-3 (A3) pasca perlakuan meningkat secara cepat menjadi 33,53\%. Rata-rata derajat parasitemia hari ke-5 (A5) pasca perlakuan meningkat menjadi 51,36\%, ditandai dengan banyaknya bentuk skizon yang ditunjukkan oleh tanda panah. Adanya skizon muda dalam sediaan darah tepi berarti dalam keadaan infeksi berat. Sedangkan rata-rata derajat parasitemia pada hari ke-7 (A7) pasca perlakuan mencapai $65,9 \%$, ditandai dengan terdapat bentuk skizon yang akan pecah yang ditunjukkan dengan tanda panah.

Persen penghambatan ekstrak etil asetat Anting-anting pada hari ke-7 pasca terapi disajikan dalam Tabel 7. Untuk menentukan dosis efektif $50 \% \quad\left(\mathrm{ED}_{50}\right)$ pada penelitian ini digunakan analisa probit \% penghambatan pertumbuhan parasit selama 7 hari dan dilanjutkan dengan analisis regresi linier. Disimpulkan bahwa dosis efektif 50\% $\left(\mathrm{ED}_{50}\right)$ tidak dapat ditentukan sebab persen penghambatan rata-rata berada di atas $80 \%$ atau dengan kata lain, tidak terdapat nilai penghambatan yang berkisar diantara $50 \%$. 
Tabel 7. Persen penghambatan pertumbuhan parasit ratarata ekstrak etil asetat Anting-anting pada hari ke-7

\begin{tabular}{|c|c|}
\hline $\begin{array}{c}\text { Dosis } \\
(\mathbf{m g} / \mathbf{g} \text { bb) }\end{array}$ & Persen penghambatan pertumbuhan parasit \\
\hline 0,01 & 87,19 \\
\hline 0,1 & 84,92 \\
\hline 1 & 90,74 \\
\hline
\end{tabular}

Dalam penelitian ini diperoleh persen penghambatan pertumbuhan parasit antara 84\%-90\% (Tabel 7). Hal ini dapat disimpulkan bahwa ekstrak etil asetat Anting-anting memiliki potensi yang sangat bagus dalam menghambat pertumbuhan parasit. Pouplin et al. (2007) mengatakan suatu ekstrak dikatakan mempunyai sifat antiplasmodium apabila dapat memberikan penghambatan parasit lebih dari $30 \%$.

Penghambatan pertumbuhan Plasmodium berghei pada penelitian ini diduga karena crude ekstrak etil asetat Anting-anting mengandung senyawa aktif yang dapat menghambat pertumbuhan parasit yaitu kandungan senyawa golongan alkaloid dan terpenoid.Kayser et al. (2000) mengatakan setiap ekstrak dan obat mempunyai mekanisme penghambatan yang spesifik, begitu pula dengan senyawa-senyawa yang berasal dari tumbuhan.

Senyawa golongan alkaloid telah diketahui dapat menghambat pertumbuhan parasit dengan menghalangi pertumbuhan parasit melalui transport intraseluler kolin (Hilou, et al., 2006). Begitu pula dengan senyawa golongan terpenoid juga telah diketahui dapat menghambat pertumbuhan Plasmodium berghei dengan cara menghambat sintesis protein pada sel mamalia dan dan juga parasit malaria (Pouplin et al., 2007).

\section{KESIMPULAN}

Ekstrak etil asetat tanaman anting-anting (Acalypha indica L.) memiliki aktifitas antimalaria.Senyawa aktif yang diduga terdapat dalam ekstrak etilasetat adalah tanin, alkaloid, dan steroid.

Uji aktivitas antimalaria secara in vivo pada hewan coba didapatkan hasil penghambatan ekstrak etilasetat terhadap pertumbuhan Plasmodium berghei pada dosis $0,01 \mathrm{mg} / \mathrm{g}$ bb sebesar $87,19 \%$; pada dosis $0,1 \mathrm{mb} / \mathrm{g}$ bb sebesar $84,9 \%$ dan pada dosis $1 \mathrm{mg} / \mathrm{g}$ bb sebesar $90,74 \%$.

\section{UCAPAN TERIMAKASIH}

Penulis menyampaikan terima kasih kepada Direktorat Pendidikan Tinggi Islam Kementrian Agama, yang memberikan bantuan dana penelitian kompetitif 2010. Ibu Roihatul Muti'ah dan Anna Nihayah serta semua pihak yang telah membantu terselesaikannya penelitian ini.

\section{DAFTAR PUSTAKA}

Ancelin M.L., \& H.J., Vial, 1989, Quaternary Ammonium Coumpounds Efficiently Inhibit Plasmodium falciparum Growth In Vitro by Impairment of Choline Transport, Antimicrobial Agent and Chemotherapy, Vol. 29, 814-820.

Anonim, 2009, Tanaman Obat Indonesia (Acalypha Indica L.), www.Iptek.Net.Id, Diakses 27 Februari 2009.

Antara News, 2007, Nyamuk Malaria di Papua Kebal terhadap Obat Cloroquin. 
http://www.antara.co.id/view/?i=1 $188324951 \& c=N A S \& s=, \quad$ Rabu, 29 Agustus 2007, Diakses Tanggal 11 Maret 2010.

Aryanti, T.M., Ermayanti, K.I., Prinadi, \& R.M., Dewi, 2006, Uji Daya Antimalaria Artemisia spp. Terhadap Plasmodium falciparum, Majalah Farmasi Indonesia, Vol. 17, No. 2, 81-84.

Baraguey C., C.A., Guette, A., Blond, F., Cavelier, F., Lezenven, J.L., Pousset, \& B., Bernard, 1998, Isolation, Structure And SynthesIs of Chevalierins A, B And C, Cyclicpeptides From The Latex Of Jatropha Chevalieri, J. Chem. Soc., Perkin Trans, Vol.1, 3033-3039.

Baraja, M., 2008, Uji Toksisitas Ekstrak Daun Ficus elastica Nois ex Blume terhadap Artemia salina Leach dan Profil Kromatografi Lapis Tipis, Skripsi, Fakultas Farmasi Universitas Muhammadiyah Surakarta, Surakarta.

Denis A.M., M.D., Dondorp, N.M.D., François, \& Y.M.D., Poravuth, 2006, Efficacy of ArtemetherLumefantrine for The Treatment of Uncomplicated Falciparum Malaria In Northwest Cambodia, Tropical Medicine and International Health, Vol.1, No. 12,1800-1807, http://www3.interscience.wiley.co $\mathrm{m} /$ cgibin/fulltext/118598662/, Diakses Tanggal 26 Juli 2009.

Handayani D., N., Sayuti \& Dachriyanus, 2008, Isolasi dan Karakterisasi Senyawa Antibakteri Epidioksi Sterol dari Spon Laut Petrosia nigrans, Asal Sumatera Barat, Prosiding Seminar Nasional Sains dan Teknologi-II 2008,

\author{
Universitas \\ Lampung. \\ Lampung,
}

Hayati, E.K., A.G., Fasya, \& L., Saadah, 2010, Fraksinasi dan Identifikasi Senyawa Tanin Pada Daun Belimbing Wuluh (Averrhoa bilimbi L.), Jurnal Kimia (Journal of Chemistry), Vol. 4 No. 2.

Hilou, A., O.G., Nacoulma, \& T.R., Guiguemde, 2006, In vivo Antimalarial Activities of Extracts Amaranthus Spinosus L. and Boerhaavia erecta L. in Mice, Journal or Ethnopharmacologhy, Vol.103, 236-240

Ipteknet, 2005, Tanaman Obat Indonesia Anting-Anting (Acalypha Australis Linn.), BPPT, Jakarta, Diakses 27 Februari 2007.

Kusnaeni, V., 2008, Isolasi dan Karakterisasi Senyawa Fraksi nHeksana dari Ekstrak Kulit Batang Angsret (Spathoda campanulata Beauv), Skripsi, Jurusan Kimia, Fakultas MIPA, Universitas Brawijaya, Malang.

Muti'ah, R., 2010, Aktivitas Antimalaria Ekstrak Batang Talikuning (Anamirta cocculus) dan Kombinasinya dengan Artemisin pada Mencit yang Diinfeksi Plasmodium berghei, Tesis, Program Pasca Sarjana Fakultas Kedokteran Universitas Brawijaya, Malang.

Nindatu, Maria, 2008, Efek Antimalaria Senyawa Flavonoid Kulit Batang Cempedak (Artocarpus champeden Spreng) Pada Morfologi Dan Aktivitas Biokimiawi Parasit Malaria, Desertasi, Universitas Airlangga, Surabaya.

Octavia, D.R., 2009, Uji Aktivitas Penangkap Radikal Ekstrak 
Petroleum Eter, Etil Asetat dan Etanol Daun Binahong (Anredera Corfolia (Tenore) Steen) dengan metode DPPH (2,2-difenil-1- pikrihidrasil.), Skripsi, Fakultas Farmasi Universitas Muhamadiyah, Surakarta.

Pillay P., R., Vleggaar, V.J., Maharaj, P.J., Smith, \& C.A., Lategan, 2007, Isolation And Identification of Antiplasmodial SesquiterpeneLactones From Oncosiphon Piluliferum, Journal of Ethnopharmacology, Vol. 112, 71-76.

Pouplin, J.N., T.H., Tran, C., Dolecek, T.A., Phan, J., Farrar,P., Carron, B., Bodo, \& P., Grellier, 2007, Antimalarial and Cytotoxic Activities of Ethnopharmacologically

Selected Medicinal Plants from South Vietnam, Journal of ethnopharmacology, Vol. 109.

Runadi, D., 2007, Isolasi dan Identifikasi Alkaloid dari Herba komfrey (symphytum officinale 1.), Karya Ilmiah, Universitas Padjadjaran Fakultas Farmasi, Jatinangor.

Sardjono, T.W., \& L.E., Fitri, 2007, Malaria Mekanisme Terjadinya Penyakit dan Pedoman Penanganannya, Revisi Ketiga, Laboratorium Parasitologi FK Universitas Brawijaya, Malang.

Sriwahyuni, 2010, Uji Fitokimia Ekstrak Tanaman Anting-anting (Acalypha indica L.) dengan Variasi Pelarut dan Uji Toksisitas dengan Menggunakan Brine Shrimp, Skripsi, Jurusan Kimia Fakultas Sains dan Teknologi UIN Maliki, Malang.
Syamsudin, S., Tjokrosonto, S., Wahyuono, \& Mustofa, 2007, Aktivitas Antiplasmodium dari Dua Fraksi Ekstrak n- Heksana Kulit Batang Asam Kandis (Garcinia parvifolia Miq), Majalah Farmasi, Universitas Gajah Mada, Yogyakarta.

Tahir, I., Mudasir, I., Yulistia \& Mustofa, 2005, Quantitative Quantitative Structure Activity Relationship Analysis (Qsar) of Vincadifformine Analogues As The Antiplasmodial Compounds of The Chloroquinosensible Strain. Indo. J. Chem., Vol. 5, No.3, 255-260.

Wei-Fang, D., L., Zong-Wen, \& S., HanDong, 1994, A New Compound From Acalypha Australis L. Laboratory of Phytochemistry, Kunming Institute of Botany, Chiese Academy of Sciences.

Widodo, N., 2007, Isolasi dan Karakterisasi Senyawa Alkaloid Yang Terkandung Dalam Jamur Tiram Putih (Pleurotus Ostreatus), Skripsi, Jurusan Kimia Fakultas Matematika dan Ilmu Pengetahuan Alam, Universitas Negeri Semarang, Semarang.

www.Iptek.Net.Id. Tanaman Obat Indonesia (Acalypha Indica L.), Diakses 27 Februari 2009

Zambrut, A.A., D.M., Gusmali \& M.H., Mukhtar, 2001, Aktivitas Antimalaria Senyawa Tinokrisposid Secara in vivo, Cermin Dunia Kedokteran, Universitas Negeri Semarang, Vol. 131, 27-31. 